\title{
Dispatch
}

\section{Intimate Labour and Social Justice: Engaging with the Work of Rhacel Salazar Parreñas}

\author{
ROBYN LEE \\ University of Alberta, Canada \\ RHACEL SALAZAR PARREÑAS \\ University of Southern California, USA
}

\begin{abstract}
Although work and care have received substantial attention from academics and activists, and so have bodily exchanges for the purposes of remediating injury or illness and providing for reproductive needs, it has only been recently that the intersections of care, labour and bodily exchanges have been addressed. Rhacel Salazar Parreñas' understanding of intimate labour was formative in understanding the intersections of bodies, labour, care and social justice in the Consuming Intimacies symposium, which explored care work and social reproduction, reproductive labour, and the role of affect and care in exchanges of bodily tissues, fluids, and organs. Parreñas' work was integral to the conceptualization of the symposium and this special issue, and she participated as a keynote speaker and conference attendee.

I have long been familiar with Parreñas' work, and over the course of the symposium and afterward, I reflected extensively on the role played by the concept of intimate labour on the development of the Consuming Intimacies project and the impact of Parreñas' work on my research on breastfeeding as care work and emerging transnational markets in breast milk. Recognizing the important role intimate labour plays in connecting the often divided fields of work and care, in this brief reflection I draw on an interview I conducted with Parreñas, our conversations throughout the conference, her work, and her keynote address to identify what it means for scholars to work on social justice, and to share thoughts on future opportunities for social justice work on intimate labour. Drawing on our mutual interest in Foucault's understanding of technologies of the self, I examine how our work on
\end{abstract}


transnational markets in intimate labour intersects in exploring both risks of exploitation and also potential for transforming gender practices and identities.

Parreñas defines intimacy as a particular type of association or relationship between two or more individuals, one that involves the sharing of knowledge and attention that are not widely available to third parties. The work of tending to the intimate needs of individuals encompasses a vast array of labour. By combining care work, sex work, and domestic work, she examines intimacy as a material, affective, psychological, and embodied state.

Intimate labour refers to the work of forging, sustaining, nurturing, maintaining and managing interpersonal ties, as well as the work of tending to the sexual, bodily, health, hygiene, and care needs of individuals (Parreñas $\&$ Boris, 2010) The concept of intimate labour brings together the oftenseparated categories of care work, domestic work and sex work, calling attention to the labour involved in tending to the intimate needs of individuals inside and outside their home. Although intimate relations are often thought to be limited to the private sphere, in fact intimacy has always inhabited the market and public settings. Not only does intimate labour blur the divisions between productive and reproductive labour, the work itself simultaneously entails both production and reproduction.

Parreñas' theorization of intimate labour in ways that encompass commonly discrete categories such as private and public, productive and reproductive labour, has been integral to my research on breastfeeding and human milk exchange. This is because the work involved in producing and exchanging human milk crosses various conventional categories of work and care. Producing breast milk may be variously understood as a physiological or sociocultural process, as care or labour. The lines between bodily exchange, care, and economy are increasingly blurred in the intimate labour involved in milk sharing, milk banking, and the buying and selling of human milk. As Parreñas defines it:

[Intimate labour] entails touch, whether of children of customers; bodily or emotional closeness or personal familiarity, such as sexual intercourse and bathing another; or close observation of another and knowledge of personal information, such as watching elderly people or advising trainees. Such work occurs in homes, hospitals, hotels, streets, and other public as well as private locations. It exists along a continuum of service and caring labor, from high-end nursing to low-end housekeeping, and [as noted earlier] includes sex, domestic, and care work. (Parreñas \& Boris, 2010, p. 2).

Various groups of feminists have divergent views on the intersections of love and money, and thus competing views on intimate labour. Parreñas follows Viviana Zelizer (2007) on the commercialization of intimacy, in her argument that all monetary transactions - including those most intimate in our society - are embedded in social relations. In short, the social meanings 
of intimate monetary transactions depend on the relations and the context, resulting in their multiple meanings.

The study of "markets of intimacy" examines the firms (e.g., surrogacy clinics, sperm banks, adoption agencies, marriage brokering firms, long term care facilities), product markets (e.g., surrogacy, sexual reassignment surgery, care), and niche labour markets (e.g., of health care, sex work, and domestic work) that produce and reproduce intimate relations and identities with scholars attuned to the cultural meanings, and social-economic processes.

Parreñas' research has been tremendously influential in the areas of globalization, migration, gender, and care. She has investigated how care operates at a distance and how family relations and consumption are being transformed in an era of globalization (Parreñas, 2005, 2011, 2015). Her research has been important to the work of many scholars in the fields of transnational migration, precarious labour, domestic and care work, the commodification of intimacy, reproduction labour, and transnational families.

Increasingly, markets in care work and bodily exchanges are transnational in scope. In her widely-cited books Servants of Globalization: Women, Migration and Domestic Work (Parreñas, 2015) and Children of Global Migration: Transnational Families and Gendered Woes (Parreñas, 2005) she explores transnational markets in intimate labour and the impact of these exchanges of intimate labour on the workers and their families. Parreñas describes how migrant domestic workers act as "servants of globalization," leaving their own children behind in order to care for the children of families in the global north. Parreñas investigates the effects this has on the children left behind, in the Philippines particularly, and how mothering is redefined in the process. She finds that the gendering of parenting roles remains resistant to change, even as mothers take on the role of providing financial support for their families by working overseas. State policies, religious constitutions, educational institutions, and community groups in the Philippines all react negatively against transnational, breadwinning mothers, influencing children to view their mothers as having "abandoned" them. Fathers are viewed much more positively when they leave the family in order to act as breadwinners, in line with traditional gender roles. As well, when mothers leave, fathers are less likely to take on caregiving responsibilities, instead often leaving care of their children to other women: aunts, grandmothers, close friends, and sisters. The act of migration enables fathers' fulfillment of masculine responsibilities, while mothers are predominantly viewed as having abandoned their children.

Although Foucault is well known for his attention to power and domination, in his concept of technologies of the self he explores how individuals work on themselves, their bodies, thoughts, and behaviour in order to transform themselves (Foucault, 1988). Technologies of the self are not merely invented by individuals: they are the result of broader social 
forces and practices of power. However, they represent opportunities to creatively engage with power structures. Foucault's concept of technologies of the self is useful in capturing the ambivalence and tensions inherent in feminist attention to markets in intimacy, as these markets involve both possibilities for challenging norms of gender, embodiment, and intimacy, while also posing risks for exploitation and harm.

Parreñas' keynote address at the Consuming Intimacies symposium drew on Foucault's notion of technologies of the self in order to explore how practices of intimate labour forge identities, enable self-actualization, and allow self-growth. She argued that intimate labour, although embedded in relations of inequality, is not just a mechanism of reproducing inequality but can also be considered an instrument of self-actualization and self-valuation. Parreñas notes that sociologists often look at how people are subjugated, without recognizing the pleasures, the self-growth, and the improvements people feel that they make when they relocate. It is essential to also look at how people actually grow in carrying out transnational practices of intimate labour. For instance, when a Filipino domestic worker in the Middle East was asked what she had gained from this experience, her response described exposure to new cuisines that wouldn't have occurred if she had just stayed in the Philippines. In carrying out research on transnational markets in intimate labour, Parreñas believes it is important to look at the broad range of workers' experiences, in terms of both exploitation and potential growth and transformation.

Parreñas found that women's moral boundaries expanded through migration and exposure to intimate labours. In our interview, Parreñas described how during fieldwork she met some nuns whose primary job is to carry out "apostolic work" with migrant Filipino hostesses. One nun told her:

Before I came here, and I got assigned here, I thought that god was punishing me because he was taking me to the land of Sodom and Gomorrah. But after being here for a while, I realized these women were not like all bad, right? That each has their own reason for being here and that each, you know has their own you know standards of what's acceptable to them about using their sexuality to get ahead.

The nuns came to realize that the women performing sex work they didn't approve of were doing it for a greater good: sending their kids to school, feeding their family, sending a sibling to school, and social mobility. Parreñas found it striking that even nuns became a little bit more tolerant of work that's usually dismissed as immoral, through their social interactions with the women who performed it. In turn, the women working as hostesses would turn to the nuns for help when they had difficulties.

Parreñas' current work calls attention to the unfree labour of migrant workers, and the associated social justice intervention she considers to be most pressing is the greater recognition of the humanity of migrant workers. She notes that in effect they are working in servitude as a result of being contractually obligated to work, unable to leave until the end of their 
contract. She points to the United Arab Emirates, Saudia Arabia, and Singapore as being the worst, as in these countries it is not possible to quit your job without permission from your employer. In other places, like Hong Kong, you can leave your job at any time, but you need to find a new job within two weeks or else you have to leave the territory. For a long time Parreñas thought what migrant workers needed was personal autonomy and the freedom to control their situation. However, she ultimately realized that this view represented an overinvestment in the neoliberal project of "the self," drawing on Foucault's critique. She consequently came to believe that the workers' humanity must be recognized: employers need to realize that as humans, workers have certain needs to sleep and rest as well as for freedom and bodily autonomy. Unfortunately many people working in servitude find that their humanity is not recognized. Parreñas argues that this needs to change.

The social justice work of examining intimate labour continues to spark debate among academics and activists. The commercialization of intimate labour poses risks of exploitation for workers, particularly along racialized, classed, and global lines of inequality. However, it also produces possibilities for challenging and transforming gendered norms of embodiment and conventional morality. In order to critically assess transnational markets in intimacy, it is necessary to examine the particular circumstances of the labour, in order to distinguish between exploitation and potential for resistance. As well, it is essential to recognize the ongoing influence of hierarchies of race, class, culture, and geography, as they have profound effects on practices of intimate labour.

\section{References}

Foucault, M. (1988). Technologies of the self: A seminar with Michel Foucault. (L. H. Martin, H. Gutman, \& P. H. Hutton, Eds.). Amherst, MA: University of Massachusetts Press.

Parreñas, R. (2005). Children of global migration: Transnational families and gendered woes. Stanford, CA: Stanford University Press.

Parreñas, R. (2011). Illicit flirtations: Labor, migration, and sex trafficking in Tokyo. Stanford, CA: Stanford University Press.

Parreñas, R. (2015). Servants of globalization: Migration and domestic work. (2 ${ }^{\text {nd }}$ ed.). Stanford, CA: Stanford University Press.

Parreñas, R., \& Boris, E. (Eds.). (2010). Intimate labors: Cultures, technologies, and the politics of care. Stanford, CA: Stanford Social Sciences.

Zelizer, V. A. (2007). The purchase of intimacy. Princeton, NJ: Princeton University Press. 